The explanation of the difference between the present results and those of MacDonald et al. (1967) is uncertain. The mean rise of $93 \%$ in airway resistance which they reported may have been due partly to a decrease in lung volume, since they do not quote values for the latter, but this is unlikely to have been enough to account for the whole response, particularly since propranolol did not significantly alter Vtg in the present experiments (see Table).

Another possible factor is the timing of measurements, since MacDonald et al. (1967) compared control values of airway resistance with peak response values, which sometimes occurred as soon as two minutes after the injection and always within 20 minutes. Our first set of measurements were made 8 to 12 minutes after injection and are therefore unlikely to have missed many peak responses, but even when only this set of measurements was compared with the control values there was no significant change in SGaw.

Although the above two factors may have played a small part, the most probable explanation of the difference in results is that of subject selection. There is wide variation in individual response to propranolol, five out of 18 subjects reported by MacDonald et al. (1967) showing increases of airway resistance of less than $15 \%$ and two of $300 \%$ or more. Three of our 10 normal subjeots showed a distinct fall in SGaw after propranolol, though the change in the group as a whole was not significant. The absence of clinically important $\beta$-adrenergic bronchodilator activity in non-asthmatic subjects is confirmed by the rarity of respiratory symptoms in hypertensive patients treated with large doses of propranolol (Prichard and Gillam, 1969).

The decrease in SGaw seen in the present asthmatic subjects confirms previous findings of a bronchoconstrictor response to propranolol (McNeill, 1964; Zaid and Beall,
1966 ; Langer, 1967 ; MacDonald et al., 1967). Even mild asthmatics thus appear to have increased $\beta$-adrenergic bronchodilator activity at rest, which persists despite the absence of symptomatic airway obstruction.

We should like to thank Dr. J. C. Batten for his advice and encouragement, and Miss F. A. Boother and Mrs. J. Unwin fợ their technical help. One of us (G. M. S.) was supported by research grant from the Board of Governors, St. George's Hospitas, London.

\section{REFERENCES}

DuBois, A., Botelho, S. Y., Bedell, G. N., Marshall, R., and Comro@ J. H., jun. (1956a). Fournal of Clinical Investigation, 35, 322. DuBois, A. B., Botelho, S. Y., and Comroe, J. H., jun. (1956b). foumin of Clinical Investigation, 35, 327.

Guyatt, A. R., Alpers, J. H., Hill, i. D., and Bramley, A. C. (19672 fournal of Applied Physiology, 22, 383 .

Langer, I. (1967). Fournal of Physiology, 190, 41P. Proceedings of $24 \mathrm{th}$ International Congress of Physiological Sciences $7,273$.

McCulloch, M. W., Proctor, C., and Rand, M. J. (1967). Europeakn

Fournal of Pharmacology, 2, 214.
MacDonald, A. G., Ingram, C. G., and McNeill, R. S. (1967). Britis Fournal of Anaesthesia, 39, 919 .

McNeill, R. S. (1964). Lancet, 2, 1101.

McNeill, R. S., and Ingram, C. G. (1966). American fournal of Cardio $\vec{A}$

logy, 18, 473 .
Marcelle, R., Bottin, R., Jachmes, J., and Lecomte, J. (1968). Acto Allergologica, 23, 11 .

Nadel, J. A., and Comroe, J. H., jun. (1961). fournal of Applied Physio logy, 16, 713. Prichard, B. N. C., and Gillam, P. M. S. (1969). British Medical fourna

Severinghaus, J. W., and Stupfel, M. (1956). Fournal of Applied Physio= $\log y, 8,81$.

Sterling, G. M. (1967). British Medical fournal, 3, 275.

Sterling, G. M. (1968). Clinical Science, 34, 277

Widdicombe, $\mathrm{J}$ edited by

Zaid, G., and Beall, G. N. (1966). New England fournal of Medicino 275,580 .

\title{
Dietary Sugar and Ischaemic Heart Disease
}

\author{
R. W. HOWELL,* F.M.R.: ; D. G. WILSON, $\dagger$ M.B., D.I.H., D.oBST.R.C.o.G.
}

Summary : Comparison of the sugar intake of 1,158 men 1 believed to be free of ischaemic heart disease failed to establish any real difference in intake when compared with 170 men with confirmed or possible ischaemic heart disease. In neither group was there any significant correlation between sugar intake and serum cholesterol, white blood cell count, haemoglobin, E.S.R., $\beta$-lipoprotein, or uric acid; nor was there any correlation between total sugar intake and weight gain after the age of 25 years.

These results suggest that considerably more confirmation is required before acceptance of Yudkin's hypothesis that high sugar intake is the chief dietary factor causing ischaemic heart disease.

\section{Introduction}

Considerable interest has been aroused by the proposition (Yudkin, 1957) that high sugar intake is the chief dietary factor causing ischaemic heart disease (I.H.D.). This suggestion has not been sustained in man in any large inquiry; indeed,
Paul, MacMillan, McKean, and Park (1968) found " nothing like the twofold difference in sucrose intake between coronaryo and non-coronary groups desoribed by Yudkin and Roddy."W Results from other countries, however, are not always repro ducible in Britain, and further reports are essential. In thise survey an attempt has been made to relate sugar intake to ischaemic heart disease from a prospective five-year heart study. now being carried out at four U.K. Atomic Energy Authority establishments.

\section{Patients and Methods}

The survey population of 2,700 was a random male sample born in the years 1912 to 1926 inclusive. Over $90 \%$ of those originally selected have entered the survey (though those not free from I.H.D. at entry will have to be omitted from most

\footnotetext{
* Authority Health and Safety Branch, Harwell, United Kingdom Atomic Energy Authority.

t Medical Officer, Dounreay Experimental Reactor Establiahment,
United Kingdom Atomic Energy Authority.
} 
analyses), so that the participants may reasonably be regarded as representative of the male population of that age at those establishments.

Each man was given a self-administered questionary designed by Yudkin (Yudkin and Morland, 1967) to avoid observer bias ; after completion of the questionary, details were punched into standard 80-column cards. A computer operation calculated the weekly sugar intake for each man and produced a summary card showing his overall consumption and subtotals in a number of subgroups, such as beverages. Medical officers did not have details of sugar consumption for individuals (this was calculated and retained outside the participating establishments) and were thus able to classify men into I.H.D. categories without subconscious bias.

Such a questionary is bound to have some limitations and ambiguities, though Yudkin (1964) showed it to be reliable. When the survey population is divided into those free of I.H.D. and those with definite or possible I.H.D., minor defects should be common to both groups. Clearly, this report suffers from the fact that it omits patients who have died suddenly (it is a prevalence study), but so too did those of Yudkin and Roddy (1964) and Yudkin and Morland (1967), which, using the questionary, showed a much higher sugar intake in I.H.D. patients. Nevertheless, if Yudkin's proposition be valid, the I.H.D. patients in this survey could be expected to show some real excess in sugar intake over the normal control group. This report is based on the first 1,328 men examined during 1968 out of a total of 2,700 in the survey. There is no significance in this number of 1,328 ; at a point when it was convenient to begin the analysis this was the number available. There is no reason to suspect that these 1,328 were especially selected from the total number in the survey. A further paper from this survey (Crown, Duncan, and Howell, 1969) gives reasons and supporting figures to show that the order in which the men were examined did not introduce bias.

\section{Diagnostic Criteria}

History.-In the course of the routine annual examination the examining medical officers followed up general questions about well-being with specific questions about pain, tightness, or discomfort in the chest, and, when present, with questions regarding its site, character, duration, area of radiation, and aggravating and relieving factors.

Clinical Examination.-General clinical examination of all systems included particular attention to the cardiovascular system. Pulse rate and rhythm were noted, as also were quality of heart sounds, character of murmurs if any, state of retinal vessels, presence of peripheral pulses (posterior tibial and dorsalis pedis arteries), and blood pressure (systolic, sound change, and sound disappearance).

Electrocardiogram.-A 12-lead electrocardiogram was carried out on every man and reported on by the examining medical officers, who completed, each time, a form which questioned the characteristics of each component of the E.C.G. complex and in which leads deviations from normal were found-for example, an arrow up or down in the box for any lead in which the S-T segment was raised or depressed by more than $1 \mathrm{~mm}$. Similarly, a "tick" in the appropriate box where $\mathrm{T}$ wave showed less than $1 \mathrm{~mm}$. deflection; and again where $\mathrm{T}$ waves were inverted.

The criteria for myocardial anoxia have been $\mathrm{S}-\mathrm{T}$ segment depression and/or T-wave inversion in I, aVL, or III, aVF, and V4-6. World Health Organization Technical Report Series 168 has been the guide for myocardial infarction, but invariably this definitive diagnosis has been made on clinical, E.C.G., and biochemical grounds by a consultant physician in the hospital to which the patient has been admitted. "Possible" I.H.D. was diagnosed when the employee presented with a typical history but E.C.G. changes were absent or less than the criteria described, or when E.C.G. changes which met the criteria existed but there was no typical history. "Definite" I.H.D. was diagnosed in the presence of both typical history and E.C.G. changes.

\section{Results}

Of these 1,328 men, $170(12 \cdot 8 \%)$ were classified as definite or possible sufferers from I.H.D. The definite cases were all diagnosed in hospitals, and clearly it would be impossible to define exact criteria used in all hospitals. It can be said, as Yudkin and Roddy (1964) said, that definite cases were diagnosed by consultant physicians on the basis of history, clinical examination, and E.C.G. The paper of Paul et al. (1968) did not define criteria for diagnosis other than "no cases with a diagnosis solely of angina pectoris were included."

Of these 170 men, 111 were classified as possible sufferers largely on the basis of E.C.G. findings. Though such limited criteria have disadvantages discussed later in connexion with tables restricted to these men only, this group does have the advantage that the men have not yet changed their sugar habits as may happen after a frank attack. Yudkin (1966) found that in an attempt to lose weight after a first attack of myocardial infarction, patients' sugar intake fell so that after 18 months it was similar to that of controls. On the other hand, Howell (1966) reported that overweight infarction patients at Atomic Energy Authority establishments seldom lost weight in the long run.

Table I shows that no significantly higher sugar intake could be attributed, in this series, to the I.H.D. group, and Table II shows that, unlike the series of Paul et al. (1968), there was no real difference in the number of cups of coffee consumed. Nor was there any striking difference in the daily consumption of tea in this series.

\begin{tabular}{ll|c|c|c|c}
\multicolumn{8}{c}{ TABLE II.-Mean Daily Intake of Hot Drinks (Cups) } \\
\hline
\end{tabular}

There was no significant correlation between total sugar 2 intake and serum cholesterol in either the control group 0 or the I.H.D. groups. Dalderup, Doornbos, and De Vries $\mathbb{\Phi}$ (1968) concluded that habitual high sugar consumption does ? not necessarily raise the serum cholesterol level. No relation ${ }_{0}^{0}$ could be shown in any group between total sugar intake and any of the laboratory tests shown in Table III, nor was there . ,

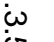 . . . . 。 . 官}


any correlation between total sugar intake and weight gain since the age of 25 years.

TABLE III.-Laboratory Test Results in Controls and I.H.D. Groups

\begin{tabular}{|c|c|c|c|c|}
\hline Mean & $\begin{array}{l}1,158 \\
\text { Controls }\end{array}$ & $\begin{array}{c}107 \text { I.H.D. } \\
\text { Patients with } \\
\text { Unchanged Sugar } \\
\text { Habits in Past } \\
10 \text { Years }\end{array}$ & $\begin{array}{l}59 \\
\text { Confirmed } \\
\text { I.H.D. } \\
\text { Patients }\end{array}$ & $\begin{array}{l}29 \text { Confirmed } \\
\text { I.H.D. Patients } \\
\text { with Unchanged } \\
\text { Sugar Habits in } \\
\text { Past } 10 \text { Years }\end{array}$ \\
\hline $\begin{array}{l}\text { White blood cell } \\
\text { count (/cu.mm.) }\end{array}$ & 6,573 & 7,756 & 8,040 & 8,939 \\
\hline $\begin{array}{l}\text { Haemoglobin (g.l } \\
100 \text { ml.) E.S.R. }\end{array}$ & $13 \cdot 6$ & $15 \cdot 0$ & $14 \cdot 5$ & $14 \cdot 7$ \\
\hline $\begin{array}{l}\text { (mm./1st hour) } \\
\text { Serum cholesterol }\end{array}$ & 6.9 & $9 \cdot 0$ & $11 \cdot 2$ & $12 \cdot 1$ \\
\hline $\begin{array}{l}\text { (mg./100 ml.) } \\
\beta \text {-Lipoprotein (mm.) }\end{array}$ & $\begin{array}{l}218 \\
2 \cdot 2\end{array}$ & $\begin{array}{l}240 \\
2 \cdot 3\end{array}$ & $\begin{array}{c}233 \\
2 \cdot 3\end{array}$ & $\begin{array}{l}235 \\
2 \cdot 3\end{array}$ \\
\hline $\begin{array}{l}\text { Uric acid } \\
\text { (mg./100 ml.) }\end{array}$ & $6 \cdot 4$ & $5 \cdot 4$ & $5 \cdot 9$ & $5 \cdot 7$ \\
\hline
\end{tabular}

It is not the purpose of this paper to discuss the variations in laboratory tests between the various I.H.D. and control groups, but it may be pointed out that the results are generally not dissimilar from one or more of the large surveys concentrating on this aspect. For example, the I.H.D. groups in Table III had cholesterol levels about $10 \%$ higher than the control group; Paul et al. (1963) showed a similar excess of $10 \%$ in their series, though others have shown larger increases (cf. Gertler, White, Cady, and Whiter, 1964). The finding of lower uric acid levels in the Atomic Energy Authority I.H.D. groups has not been generally confirmed by others; other laboratory tests gave higher levels in the I.H.D. group (Table III), though the $\beta$-lipoprotein levels are similar to those of the control group. $\beta$-Lipoprotein results, with an antihuman serum method, are read in millimetres of precipitate in a standard capillary tube, the column being measured against a scale, under magnification.

The total sugar intake in a normal population will be constantly changing as some persons increase and some decrease their sugar intake. On the other hand, the pressures on the I.H.D. group to reduce sugar intake may be greater, so that consumption may be substantially lower than before the onset of disease. Yudkin's questionary, as used in this survey, asked the men whether they had changed their sugar consumption, whether they now took more or less than hitherto, and how long ago their habits were changed. The questionaries of the 170 men in the I.H.D. group were therefore examined, and showed that 107 had not changed their habits in the past 10 years. As in the control group, very few men had increased their sugar consumption. An analysis was carried out of the records of 107 men with unchanged habits (Table IV).

TABLE IV.-Questionary Averages of Sugar Intake (g./week) of 107 Men with I.H.D. and Unchanged Sugar Intake for 10 Years (Standard Deviations in Parentheses)

\begin{tabular}{|c|c|c|c|c|c|c|c|}
\hline & \multirow{2}{*}{$\begin{array}{l}\text { Total } \\
\text { Sugar } \\
\text { Intake }\end{array}$} & \multicolumn{3}{|c|}{$\begin{array}{c}\text { Hot } \\
\text { Beverages }\end{array}$} & \multirow{2}{*}{$\begin{array}{l}\text { Sweets, } \\
\text { Choco- } \\
\text { late, } \\
\text { Fizzy } \\
\text { Drinks }\end{array}$} & \multirow{2}{*}{$\begin{array}{l}\text { Cereals, } \\
\text { Grape- } \\
\text { fruit, } \\
\text { Por- } \\
\text { ridge }\end{array}$} & \multirow{2}{*}{$\begin{array}{c}\text { Jam, } \\
\text { Biscuits, } \\
\text { Pud- } \\
\text { dings, } \\
\text { Cake }\end{array}$} \\
\hline & & Tea & Coffee & $\begin{array}{l}\text { Other } \\
\text { Drinks }\end{array}$ & & & \\
\hline & $557(3$ & $240(220)$ & $51(81)$ & $9(25)$ & $92(108)$ & $29(53)$ & $136(116$ \\
\hline group & $553(331)$ & $204(216)$ & $50(81)$ & $10(27)$ & $106(163)$ & $29(49)$ & 155 (99) \\
\hline
\end{tabular}

No real differences are discernible between this group of 107 men and the control group ; both the means and the standard deviations are very similar.

The incidence of I.H.D. rises rapidly with age, so that even within the limited range of the survey group one would expect that the average age of the I.H.D. group would be higher than that of the control group, provided that the criteria for the selection of I.H.D. patients are valid. In fact, 95 of the 170 I.H.D. group $(55.9 \%)$ were 49 years or over compared with $36.0 \%$ in the control group. Table $\mathrm{V}$ shows that no excess sugar intake was found in any age group in the I.H.D. patients, nor is there any significant difference when the results are restricted to those who have never changed their sugar habits.

TABLE V.-Questionary Averages of Sugar Intake by Age Groups

\begin{tabular}{|c|c|c|c|}
\hline & \multicolumn{3}{|c|}{ Total Sugar Intake (g./week) } \\
\hline & Under 44 Years & 44-48 Years & $49+$ Years \\
\hline $\begin{array}{l}\text { All men: } \\
\text { I.H.D. group } \\
\text { Control group }\end{array}$ & $\begin{array}{r}30 \text { men. } 487(267) \\
275 \text { men. } 567(316)\end{array}$ & $\begin{array}{r}45 \text { men. } 445(277) \\
466 \text { men. } 580(318)\end{array}$ & $\begin{array}{r}95 \text { men. } 469(304) \\
417 \text { men. } 514(350)\end{array}$ \\
\hline $\begin{array}{l}\text { Men with } \\
\text { unchanged habits: } \\
\text { I.H.D. group } \\
\text { Control group }\end{array}$ & $\begin{array}{r}16 \text { men. } 619(251) \\
178 \text { men. } 662(308)\end{array}$ & $\begin{array}{r}30 \text { men. } 516(255) \\
300 \text { men. } 650(318)\end{array}$ & $\begin{array}{r}58 \text { men. } 558(347) \\
254 \text { men. } 567(293)\end{array}$ \\
\hline
\end{tabular}

In view of the varying geographical locations of the four $\overrightarrow{0}$ establishments it is surprising how apparently similar was the $\overrightarrow{-}$ mean total sugar intake in the control group at the four loca- $\omega$ tions. The slightly greater variation between establishmentso for the I.H.D. group is probably a reflection of the smaller numbers involved.

TABLE VI.-Total Sugar Intake (Mean g./week) at Four Establishments \begin{tabular}{l|c|c|c|c|c} 
TABLE VI.-Total Sugar \\
(Standard Deviations in Parentheses)
\end{tabular}

Another possible reason for the failure to show excess sugar $\vec{\oplus}$ consumption in the I.H.D. group might be the criteria on which this group was based. Those included on the basis of E.C.G. changes alone were therefore excluded, and an analysis was made of 59 cases confirmed by hospitals (Table VII).

TABLE VII.-Questionary Averages of Sugar Intake (g./week) for $59 \stackrel{\text { ڤ }}{\text { Q }}$

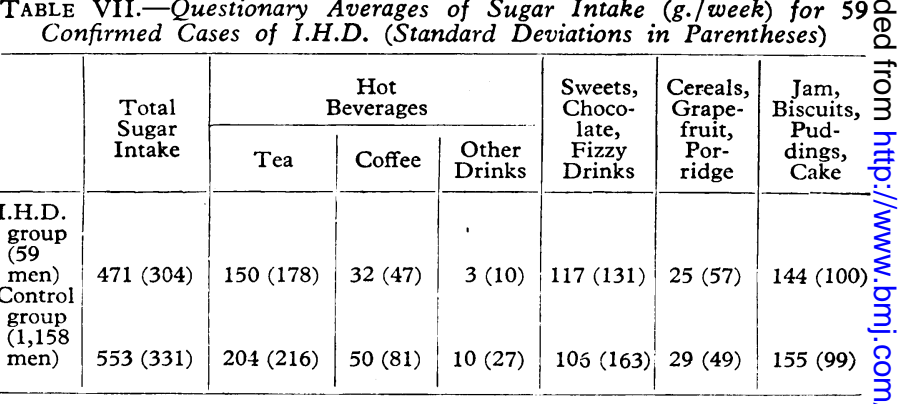

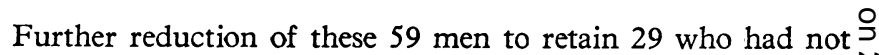
changed their sugar intake in the past 10 years again gave $\widetilde{N}$ results similar to those of a control group. On this occasion $D$ the control group consisted of 29 men nearest alphabetically to the individual I.H.D. group members when matched by age $N$ and establishment. The mean weekly sugar intake was $582 \mathrm{~g}$. N for the I.H.D. group and 509 g. for the control group (not 0 significantly different at the 0.05 level). Coffee consumption was negligible in both groups; the I.H.D. group averaged $0.81 \frac{\mathrm{C}}{\mathrm{C}}$ cup per day and the control group 1.0 cup.

\section{Discussion}

The control group in this present series had a similar mean sugar intake (553 g.) to that of Yudkin and Roddy (1964) (539 g.), but our control group had a lower sugar intake for 8 tea and coffee ( $254 \mathrm{~g}$./week on average) than the control group of Yudkin and Roddy (329 g.). Possibly the smallness of $\frac{0}{6}$ Yudkin and Roddy's sample (47 persons) contributed to this $\stackrel{?}{?}$ difference. Nevertheless, we have been quite unable to show any real increase, over the controls, in the sugar intake of I.H.D. patients, though Yudkin and Roddy (1964) and Yudkin and 
Morland (1967) had a twofold consumption in their patients with myocardial infarction, and a level almost as high as this in those with peripheral artery disease. Our results, as presented here, do not rule out the findings of Paul et al. (1968) that I.H.D. patients may have a slightly higher consumption of sucrose (not statistically significant) than controls.

As Paul et al. (1968) point out, Yudkin and Roddy's observations were made after clinical recognition of atherosclerotic disease, and on a group selected by survival. Nevertheless, using Yudkin's questionary we have been unable to reproduce his results in spite of considerable manipulation of the I.H.D. group.

The inclusion in the I.H.D. group of patients diagnosed on the findings of E.C.G. abnormalities may be open to criticism, but though not all of these patients will necessarily come to frank clinical I.H.D., the incidence of I.H.D. will certainly be far higher than in a comparable group with normal E.C.G. readings. The Framingham study (Kagan, Dawber, Kannel, and Revotskie, 1962) has shown that an E.C.G. abnormality is among the high-risk factors. Morris, Kagan, Pattison, Gardner, and Raffle (1966) have found S-T/T wave abnormality to be an important I.H.D. precursor. If Yudkin's hypothesis be valid, one would expect that sugar intake in this group diagnosed by E.C.G. would be manifestly higher than in the control group, though not at the twofold level indicated by Yudkin and Roddy. In practice this was not so. The tables using the complete I.H.D. group also have the advantage, mentioned by Paul et al. (1968), of not being entirely selected survivors. On the other hand, data collected far in advance of first coronary attack-as were the data of Paul et al. (1968)may also prove defective.
One interesting observation was that there was no correlation between total sugar intake and serum cholesterol level in either the I.H.D. or the control group. There was no correlation between sugar intake and weight gain after the age of 25 , so that clearly other dietary factors in addition to sugar intake are relevant to the problems of obesity.

These current results suggest that considerably more confirmation in man is required before Yudkin's hypothesis can be accepted.

We are glad to acknowledge our indebtedness to the other members of the survey team-Drs. J. C. Evans, A. M. Leach, and G. B. Schofield, and their staffs at Harwell, Springfields, and Windscale respectively.

\section{REFERENCES}

Crown, S., Duncan, K. P., and Howell, R. W. (1969), British fournal of Psychiatry. In press.

Dalderup, L. M., Doornbos, R., and De Vries, J. E. (1968). Lancet, 1, 819.

Gertler, M. M. White, P. D., Cady, L. D., and Whiter, H. H. (1964). American fournal of the Medical Sciences, 248, 377.

Howell, R. W. (1966). Lancet, 1, 1033 .

Kagan, A., Dawber, T. R., Kannel, W. B., and Revotskie, N. (1962). Federation Proceedings, 21, No. 4, Part 2, p. 52

Morris, J. N., Kagan, A., Pattison, D. C., Gardner, M. J., and Raffle, P. A. B. (1966). Lancet, 2, 553.

Paul, O., et al. (1963). Circulation, 28, 20.

Paul, O., MacMillan, A., McKean, H., and Park, H. (1968). Lancet, 2, 1049.

Yudkin, J. (1957). Lancet, 2, 155.

Yudkin, J. (1964). Lancet, 2, 4.

Yudkin, J. (1966). Lancet, 1, 930.

Yudkin, J., and Morland, J. (1967). American fournal of Clinical Nutrition, $20,503$.

Yudkin, J., and Roddy, J. (1964). Lancet, 2, 6.

\title{
"Normal Central Venous Pressure," Significance of Reference Point and Normal Range
}

\author{
FELIX DEBRUNNER,* M.D. ; FRITZ BÜHLER, † M.D.
}

\begin{abstract}
Cummary : The principal methods for determining the central venous pressure have been compared in 26 patients undergoing cardiac catheterization. The method in which the reference point is taken to be $10 \mathrm{~cm}$. above the surface supporting a horizontal patient gave false high-pressure values. All the other methods, however, gave pressure values which corresponded to those obtained in the catheter studies.
\end{abstract}

\section{Introduction}

The technically simple determination of central venous pressure has become a standard procedure in the intensive care unit. The central venous pressure provides a dynamic index of the effective circulation blood volume in relation to the efficiency of the right ventricle. The pressure in the superior vena cava is virtually identical with the mean pressure in the right atrium (Richards et al., 1942). The normal ranges in the first papers reporting central venous pressure measurements vary from author to author-for example, Richards et al. (1942) and Wood (1956). Recent studies agree that the normal range is about $8 \mathrm{~cm}$. of water-for example, Weil et al. (1965), Burri

\section{* Chief Resident.}

t Resident.

Department of Internal Medicine, University of Basle, Switzerland. and Allgöwer (1967), and Hardaway (1968). On the other hand, there is a complete lack of uniformity regarding the choice of the extrathoracic reference point.

In a large number of patients selected at random we measured the central venous pressure with the aid of the various methods -that is, using the various reference points-and noted that the central venous pressure value in one and the same patient varied, depending on the method used. In some cases, in fact, the values noted lay outside the normal range from the given method. If the various techniques record the same value they should yield equivalent results. As this is not the case the discrepancies noted must be due to the type of technique used. The aim of our study was to prove this point.

Our findings confirm that this hypothesis holds in six of the seven methods studied. We noticed to our surprise, however, that the remaining method, a widely used technique, deviates markedly in this respect.

\section{Method}

Twenty-six patients (18 men, 8 women) aged 39 to 79 years, with an average age of 63 , who had catheters placed in the superior vena cava directly above the right atrium, were followed by means of lateral thoracic $x$-ray films. The patients were placed horizontally on a firm surface. With the aid of a 